\title{
Investigating fish migration, mortality and physiology to improve conservation planning of anadromous salmonids: a case study on the endangered North Sea houting (Coregonus oxyrinchus)
}

Hertz, Morten; Jensen, Lasse Fast; Pertoldi, Cino; Aarestrup, Kim; Nøhr Thomsen, Søren; Alstrup, Aage Kristian Olsen; Asmus, Harald; Madsen, Søren; Svendsen, Jon Christian

Published in:

Canadian Journal of Zoology

Link to article, DOI:

10.1139/cjz-2019-0045

Publication date:

2019

Document Version

Peer reviewed version

Link back to DTU Orbit

Citation (APA):

Hertz, M., Jensen, L. F., Pertoldi, C., Aarestrup, K., Nøhr Thomsen, S., Alstrup, A. K. O., Asmus, H., Madsen, S., \& Svendsen, J. C. (2019). Investigating fish migration, mortality and physiology to improve conservation planning of anadromous salmonids: a case study on the endangered North Sea houting (Coregonus oxyrinchus). Canadian Journal of Zoology, 97, 1126-1136. https://doi.org/10.1139/cjz-2019-0045

\section{General rights}

Copyright and moral rights for the publications made accessible in the public portal are retained by the authors and/or other copyright owners and it is a condition of accessing publications that users recognise and abide by the legal requirements associated with these rights.

- Users may download and print one copy of any publication from the public portal for the purpose of private study or research.

- You may not further distribute the material or use it for any profit-making activity or commercial gain

- You may freely distribute the URL identifying the publication in the public portal 


\title{
Investigating fish migration, mortality and physiology to improve conservation planning of anadromous salmonids: a case study on the endangered North Sea houting (Coregonus oxyrinchus)
}

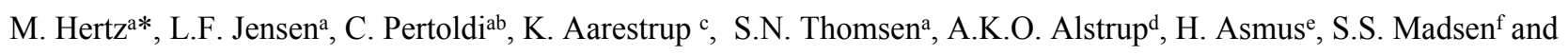
J.C. Svendseng

\begin{abstract}
aDepartment of Chemistry and Bioscience, Section of Biology and Environmental Science, Aalborg University, Fredrik Bajers Vej 7H, 9220 Aalborg Ø, Denmark, bAalborg Zoo, Mølleparkvej 63, 9000, Aalborg, Denmark, 'National Institute of Aquatic Resources, Technical University of Denmark, Vejlsøvej 39, 8600 Silkeborg, Denmark, dDepartment of Nuclear Medicine and PET Center, Institute of Clinical Medicine, Aarhus University Hospital, Nørrebrogade 44, 10C, 8000 Aarhus, Denmark, ${ }^{\mathrm{e} A l f r e d ~ W e g e n e r ~}$ Institute, Hafenstraße 43, D-25992 List, Sylt, Germany, ${ }^{\mathrm{f} D e p a r t m e n t ~ o f ~ B i o l o g y, ~ U n i v e r s i t y ~ o f ~ S o u t h e r n ~ D e n m a r k, ~ C a m p u s v e j ~ 55, ~}$ 5230 Odense M, Denmark, ${ }^{9}$ National Institute of Aquatic Resources, Technical University of Denmark, Jægersborg Alle 1, 2920, Denmark
\end{abstract}

* Corresponding author. Morten Hertz. Email: hertzmorten@gmail.com. Phone: 004528779000 


\begin{abstract}
Understanding migratory behavior, mortality and physiology is essential for conservation of many species, in particular anadromous fish. In this study, freshwater and marine migrations of the endangered salmonid North Sea houting (Coregonus oxyrinchus, Linnaeus, 1758) were investigated using telemetry. Furthermore, physiological samples were collected from North Sea houting and from resident and anadromous populations of the closely related European whitefish (Coregonus lavaretus, Linnaeus 1758) to compare hypo-osmotic tolerances. On average, North Sea houting spent 193 days at sea where the mortality was $36 \%$. Most fish returned from sea in the autumn, and river entry correlated inversely with river temperature and positively with discharge. Fish spent an average of 49 days in the estuarine area. Artificial lakes negatively affected migration speeds. Migration speeds did not differ consistently between individuals (i.e. not a repeatable trait), but correlated positively with water temperature. Fish arrived at spawning areas in November. In the post-spawning state, $\mathrm{Na}^{+} / \mathrm{K}^{+}$-ATPase activities were elevated in North Sea houting and anadromous whitefish compared to resident whitefish, while osmolality was elevated only in North Sea houting. Our study provides important information for conservation planning related to the Habitat Directive of the European Union that lists the North Sea houting as critically endangered.
\end{abstract}

Keywords: acoustic telemetry, Bern Convention, Coregonus oxyrinchus, fish, Habitat Directive of the European Union, $\mathrm{Na}^{+}, \mathrm{K}^{+}$-ATPase, North Sea houting, osmolality, repeatability, spawning migration. 


\section{Introduction}

Knowledge of habitat use and movements between habitats is essential for conservation of threatened species (Simpson and Mapleston 2002; Ebner and Thiem 2009), because diversity in habitat use and movements enable animals to respond to changing environmental conditions and maximize growth, reproductive success and survival (Kahler et al. 2001; Eggeman et al. 2016; Rolandsen et al. 2017). For example, many species increase fitness by performing seasonal migrations between disparate habitats. Anadromous fish species reproduce in freshwater habitats, while a major part of the somatic growth takes place in marine environments (Thorstad et al. 2016). This strategy can be advantageous, as migrants often benefit from faster growth rates and exhibit elevated reproductive output (Bohlin et al. 2001). However, migrants may also experience elevated levels of predation risk (Gowans et al. 2003; Wright et al. 2007), disease exposure (Halttunen et al. 2018), osmoregulatory requirements (Jensen et al. 2015b) and energetic costs (Forseth et al. 1999; Boel et al. 2014), as well as difficult access to the spawning areas (Aarestrup and Jepsen 1998; Svendsen et al. 2004; Thorstad et al. 2008).

The North Sea houting (Coregonus oxyrinchus Linnaeus, 1758) is an anadromous and iteroparous salmonid fish endemic to the Wadden Sea (Svendsen et al. 2018). The River Vidaa in Denmark supports the only indigenous population of North Sea houting left in the world. Previous reports have indicated that adult North Sea houting migrate into rivers to reproduce during the autumn and winter months. Larvae hatch in the early spring and presumably rely on lentic nursery areas within the river system for foraging (Jensen et al. 2015b). Juvenile North Sea houting stay in the river until they reach $3-5 \mathrm{~cm}$ in body length. At this point, they develop the ability to hypo-osmoregulate and presumably migrate into the Wadden Sea (Jensen et al. $2015 b$ ). After a period of 2-4 years at sea, the adults return to the natal river to spawn.

Historically, North Sea houting was widespread throughout the Wadden Sea. A dramatic decline of the species began in the early twentieth century, leading to extirpations of the species in both the Netherlands and Germany. These extirpations are attributed to a combination of pollution, overfishing, habitat loss as well as fragmentation caused by the establishment of migratory barriers in the rivers (Borcherding et al. 2010). Since the 1970s, numerous projects have been carried out to conserve the North Sea houting, but with 
limited success (Stoltze and Pihl 1998; Pihl and Laursen 2002; Jepsen et al. 2012; Poulsen et al. 2012; Svendsen et al. 2018).

In River Vidaa, projects eliminated migratory barriers (e.g. low head weirs) and created two artificial lakes to provide lentic foraging areas for the early life stages of North Sea houting. While the lakes may provide foraging areas for the young North Sea houting, lakes could also hamper the migration performed by later life stages of the species. Several studies have revealed migratory delays and elevated mortality when smolts (migrating juvenile salmonid) travel through lakes and reservoirs (Jepsen et al. 1998; Olsson et al. 2001; Aarestrup and Koed 2003; Stich et al. 2015). In contrast to the smolt migration, effects of artificial lakes on the migration performed by adult salmonids are largely unknown. Although artificial lakes may not elevate the mortality of the adult fish, as much as juveniles, partly because of their larger body size, artificial lakes could also delay migrating fish, because navigational cues present in the river (e.g. water current; Braithwaite and Girvan 2003)) may be absent in the lake.

In many migrating animals, it is increasingly recognized that individual decisions may have important implications (Chapman et al. 2011; Svendsen et al. 2011; Hewson et al. 2016; Crozier et al. 2017; Rolandsen et al. 2017). For example, in migrating fish, return probability and mortality rate may vary with individual behavioural traits (Hulthén et al. 2017; Armstrong et al. 2018), making measures of individual behaviours an important topic in conservation biology (Killen et al. 2016; Hirsch et al. 2017; Merrick and Koprowski 2017). If individual behaviours are repeatable (or consistent) across time and space, the behaviours may be targeted by selection and could have fitness implications. A first step towards understanding the consequences of individual variation in behaviour is therefore to assess whether traits are repeatable in individual fish i.e. whether behavioural traits differ consistently between individuals. On this basis, studies are increasingly examining the repeatability of various migratory behaviours (Vardanis et al. 2016; Hasselquist et al. 2017; Villegas-Ríos et al. 2017). Although a previous study reported repeatable circadian rhythms in migrating North Sea houting (Jensen et al. 2018b), the repeatability of other migratory behaviours in the species is unknown.

The taxonomic status of North Sea houting remains controversial. Based on morphological characters, Freyhof and Schöter (2005) declared North Sea houting extinct. According to Freyhof and Schöter (2005), 
the true North Sea houting was confined to the Rhine area in Germany and thus, the eradication of this population meant extinction of the species. The authors suggested that the remaining population in River Vidaa belongs to Coregonus maraena (Bloch, 1779) and not North Sea houting. This assessment was based on different numbers of gill rakers, assumed to represent genetic differences unambiguously. However, several genetic analyses have revealed that such morphological traits are homoplastic and not necessarily useful for depicting genetic inheritance (Østbye et al. 2005; 2006; Etheridge et al. 2012; Jacobsen et al. 2012).

Physiological traits are often connected to migratory behaviours, especially when the migration involves exposure to disparate environments. Anadromous fishes migrating from freshwater into saltwater are challenged by differences in salinity. During the transition between the two environments, salmonids change from hyper- to hypo-osmoregulation, often with implications for levels of gill $\mathrm{Na}^{+} / \mathrm{K}^{+}$-ATPase and regulation of blood osmolality. Some physiological changes start prior to the environmental transition, as a preparation for the new environment (Boel et al. 2014). Therefore, future seaward migration of individual brown trout Salmo trutta (Linnaeus, 1758) can be predicted based on levels of gill $\mathrm{Na}^{+} / \mathrm{K}^{+}$-ATPase several weeks prior to the migration (Nielsen et al. 2004). Seasonal changes, and differences between residents and migrants, in terms blood osmolality and plasma $\left[\mathrm{Ca}^{++}\right],\left[\mathrm{K}^{+}\right]$and $\left[\mathrm{Na}^{+}\right]$are usually weaker than gill $\mathrm{Na}^{+} / \mathrm{K}^{+}-$ ATPase (McCormick et al. 1989; McCormick and Björnsson 1994; Young et al. 1995; Reis-Henriques et al. 1996), suggesting that blood osmolality is a relatively weak predictor of migration. In the post-spawning state, North Sea houting are believed to migrate into full strength saltwater in the Wadden Sea ( $\geq 30 \%$ ), whereas populations of European whitefish (Coregonus lavaretus Linnaeus, 1758), either remain in freshwater or migrate into brackish waters $(\leq 15 \%)$. While these behavioural differences might rely on physiological adaptations, it is unknown if the physiology of North Sea houting differs from populations of European whitefish in the post-spawning state.

The objective of this study was to inform conservation practitioners by investigating factors that influence the migration of the North Sea houting. To date, conservation efforts for the North Sea houting, including removal of migration barriers and habitat restoration, have been insufficient (Jensen et al. 2015b; Svendsen et al. 2018). This suggests that a better understanding of the factors important for population 
development, such as migration and mortality, is much needed before successful conservation measures can be implemented. Specifically, we aimed to 1) estimate the marine mortality, 2) map the upstream spawning migration and the influence of environmental factors, and 3) compare traits related to osmoregulation in North Sea houting and European whitefish in the post-spawning state. To this end, we tagged fish with acoustic transmitters and monitored river entry and upstream migration using receivers positioned between the Wadden Sea and putative spawning areas in the River Vidaa. In addition, physiological gill and blood samples were collected from North Sea houting and European whitefish in the post-spawning state. Specifically, we tested four hypotheses: 1) river entry and migration speed are influenced by temperature and discharge, 2) artificial lakes situated in the River Vidaa affect migration speeds, 3) upstream migration speed is a repeatable trait in North Sea houting, and 4) North Sea houting exhibit elevated gill $\mathrm{Na}^{+} / \mathrm{K}^{+}$ATPase activity compared to European whitefish in the post spawning state. In contrast, blood osmolality levels were not expected to differ between North Sea houting and European whitefish.

\section{MATERIALS AND METHODS}

\section{Study area}

The River Vidaa is a lowland river located in southwestern Denmark (54 $57.761^{\prime}$ N; $8^{\circ} 39.686^{\prime}$ E) (Fig. 1). The catchment area is $1330 \mathrm{~km}^{2}$ and the mean annual discharge is 13,400 $1 \mathrm{~s}^{-1}$ (Ovesen et al. 2000). At the river outlet, the water flow is regulated by a sluice, protecting the surrounding area from flooding. The spawning population of North Sea houting is unknown, but estimated to be about 3,500 in River Vidaa (Svendsen et al. 2018). In 2009, two artificial lakes, Lake Nørresø and Lake Hestholm Kog, were established on the river (Fig. 1) to provide nursery habitats for juvenile North Sea houting (Jensen et al. 2015b; 2018b).

\section{Deployment of receivers}

A total of 16 acoustic receivers (model VR2W; VEMCO, Bedford, Canada) were deployed in a fixed array throughout River Vidaa (Fig. 1). Coverage included the river mouth, the estuarine area, river sections with and without lakes, and ended near the putative spawning areas situated $25 \mathrm{~km}$ upstream from the Wadden Sea. Throughout the study period (November $11^{\text {th }} 2014$ - February $21^{\text {st }} 2016$ ) receivers were checked for 
debris and data were downloaded at weekly intervals. Receiver data were used to reveal river entry from the Wadden Sea and the subsequent riverine migration towards the spawning areas (Fig. 1). Previous studies have indicated that receivers deployed in lowland rivers similar to River Vidaa provide $100 \%$ detection probability of tagged fish migrating past receiver sites (Aarestrup et al. 2014; 2015). Similarly, during fish upstream migration in the present study, detection on one receiver was always associated with detections on the receiver further downstream, indicating a fish detection probability of $100 \%$.

\section{Capture and tagging}

In total, 78 adult North Sea houting (total body length: $42.7 \pm 0.7 \mathrm{~cm}$ (mean $\pm \mathrm{SE})$ ) were captured in River Vidaa between $18^{\text {th }}$ November 2014 and $16^{\text {th }}$ March 2015 (Jensen et al. 2018b). Fish were captured using electrofishing or gillnetting (Jensen et al. 2018b). Each fish was anesthetized using benzocaine (VWR Chemicals; Radnor, Pennsylvania, USA; $2.55 \mathrm{mg} \mathrm{l}^{-1}$ ) (Aarestrup et al. 2015; Baktoft et al. 2016), and surgically tagged with an individually coded acoustic transmitter (model V9-2L; VEMCO, Bedford, Canada). The transmitters ( $29 \mathrm{~mm}$ long; $4.7 \mathrm{~g}$ in air) were programmed to emit a signal every 30 to $60 \mathrm{~s}$, providing a battery life of 378 days. Tagging followed standard procedures (Svendsen et al. 2011; Kristensen et al. 2017; Piper et al. 2017). Total body length (to nearest $0.1 \mathrm{~cm}$ ) was measured while each fish was anesthetized. Fish were released near the capture location following operative recovery (Jensen et al. 2018b). The body sizes of the tagged fish ensured a low ratio of transmitter mass: fish mass $(\leq 2 \%)$ and within the range where effects on the behaviour of the fish often are negligible (Brown et al. 2010). No controls were used to evaluate the effect of tagging on fish health, behaviour and survival. Previous studies have indicated, however, that long term effects of surgically implanted transmitters are often negligible (Jepsen and Aarestrup 1999; Koed and Thorstad 2001; Wilson et al. 2017). The effects of implanted transmitters in salmonid fish are generally believed to be limited (Moore et al. 1995; Connors et al. 2002). All handling and tagging procedures were in compliance with the guidelines described in permission 2012-DY-2934-00007 from the Animal Experimentation Inspectorate of the Danish Ministry of Justice as well as permission NST41501-00093 from the Danish Nature Agency. 


\section{Water temperature and river discharge}

River water temperature (to nearest $0.1^{\circ} \mathrm{C}$ ) was measured at $30 \mathrm{~min}$. intervals throughout the study period using temperature loggers (HOBO 64K Pendant logger; Onset Computer, Bourne, USA) attached to receivers 16, 10 and 5 (Fig. 1). River discharge (to nearest 10 l) measured at hourly intervals throughout study period at the river mouth (Fig. 1) was provided by Tønder Municipality.

\section{Sampling of gill $\mathrm{Na}^{+} / \mathrm{K}^{+}$-ATPase and blood osmolality}

To compare traits related to hypo-osmoregulation between North Sea houting and anadromous and resident populations of European whitefish, fish were sampled for measurements of gill $\mathrm{Na}^{+} / \mathrm{K}^{+}$-ATPase activity and blood osmolality (Saoud et al. 2007). In the spring 2016, 51 North Sea houting and 30 anadromous and 18 resident whitefish were caught using gill nets similar to previous studies (Jensen et al. 2018b). North Sea houting were captured in the fresh water reservoir near the river mouth of River Vidaa (Fig. 1), while anadromous and resident whitefish were captured in Ringkøbing Fjord ( $\left.55^{\circ} 59.645^{\prime} \mathrm{N} ; 8^{\circ} 13.958^{\prime} \mathrm{E}\right)$ and

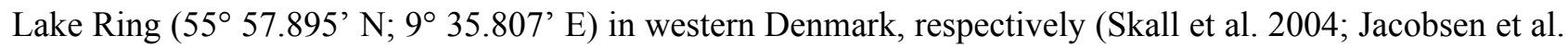
2012). Fish were held in 601 containers with aerated local water and transferred to a container with a solution of benzocaine (VWR Chemicals; Radnor, Pennsylvania, USA; $2.55 \mathrm{mg} \mathrm{l}^{-1}$ ) prior to sampling. Data on total length (to nearest $0.1 \mathrm{~cm}$ ) and body mass (to nearest $1 \mathrm{~g}$ ) were collected. A volume of $0.1 \mathrm{ml}$ of blood was collected from the caudal vein using a heparinized syringe and needle following standard procedures (Boel et al. 2014). Three to five gill filament tips, each 2-3 mm long, were removed with a pair of fine suture scissors and stored frozen in SEI-buffer $(250 \mathrm{mM}$ sucrose, $10 \mathrm{mM}$ EDTA, $50 \mathrm{mM}$ imidazole, $\mathrm{pH}$ 7.3) until analysis of $\mathrm{Na}^{+} / \mathrm{K}^{+}$-ATPase (McCormick 1993; Aarestrup et al. 2000). All samples were immediately transferred to a liquid nitrogen container (Model BS2004, CryoDiffusion, Verdun, France) and stored at minus $80{ }^{\circ} \mathrm{C}$ until analysed (Boel et al. 2014). After operative recovery, fish were released (Jensen et al. 2018b). All fish survived the procedure. No controls were used to evaluate the effect of sampling. This sampling method is, however, reported to have no effects on gill $\mathrm{Na}^{+} / \mathrm{K}^{+}$-ATPase activity, growth rate or survival of fish (Rodgers et al. 1987; Mccormick 1993). This suggests that the procedures had negligible effects on the sampled fish. Note that no fish sampled for gill $\mathrm{Na}^{+} / \mathrm{K}^{+}$-ATPase activity or blood osmolality 
were used for the telemetry study. Gill $\mathrm{Na}^{+} / \mathrm{K}^{+}$-ATPase activity was analyzed by the standard method of Mccormick (1993) in gill homogenates, using a microtitre plate reader (Spectramax Molecular Devices, Sunnydale, CA, USA). Protein content in tissue homogenates was measured at $280 \mathrm{~nm}$ using a NanoDrop Spectrophotometer (ND-1000, NanoDrop Technologies, Inc. Wilmington, USA) and calculated by using a bovine serum albumine standard curve. Blood samples were diluted (1:5) in deionized water and total osmolality was determined using a freezing point depression osmometer (Osmomat 030, Gonotec, Berlin, Germany) (Piironen et al. 2013).

\section{Data analyses}

The seaward migration of the tagged North Sea houting in the spring 2015 was described by a previous study (Jensen et al. 2018b). The present study examined time and mortality at sea and the subsequent upstream migration towards the spawning areas (Fig. 1).

Time spent at sea was estimated as the temporal difference between the last detection on the most downstream receiver (receiver 16; Fig. 1) during the downstream post-spawning migration in the spring of 2015 and the first subsequent detection on receiver 16 later in 2015. Marine mortality was estimated as the proportion of individuals leaving the river during seaward migration (spring 2015) and not returning to the river before the spawning season (i.e. before January 2016). To examine the influence of body size on marine mortality, a binomial logistic regression model was fitted using the data describing mortality (1) or no mortality (0) for the individual fish as the dependent factor and the associated body size as the independent factor (Koed et al. 2006). Following previous salmonid studies (Aarestrup et al. 2014; 2015), the approach does not account for the possibility of fish skipping a spawning season and returning to the river after two summers in the Wadden Sea. The extent of skipped spawning in mature salmonids is largely unknown, however, a previous study on North Sea houting suggested that the percentage of the mature population that skip spawning is less than 5\% (Christensen and Hvidt 1990).

The first detection of returning individual fish at the river mouth (i.e. receiver 16; fig. 1) was also used to examine environmental variables affecting river entry from the Wadden Sea. Fish that did not return to the river were excluded from these analyses. On a daily basis, receiver data were separated into river entry and 
no river entry for the individual North Sea houting (Svendsen et al. 2004). Using these data, binomial logistic regressions with river entry data as the dependent factor and river discharge or temperature as independent factors were conducted (Svendsen et al. 2004).

For the individual fish, time spent between receiver 16 and receiver 13 was used to estimate time spent in the estuarine area (Fig. 1). Initiation of upstream migration was defined as the first detection on receiver 13, whereas the first detection on receiver 1,2, 5 or 6 was used to estimate arrival time in the spawning areas (Fig. 1). Receivers 1, 2, 5 or 6 were positioned in the vicinity of the putative spawning areas (Fig. 1).

The duration of the upstream migration was estimated as the time spent between receiver 13 and the most upstream receivers (receiver 1,2, 5 or 6 ; depending on migration route). The instantaneous loss per kilometer was calculated as $\ln \left(\mathrm{F}_{\text {mig }} \times \mathrm{F}_{\text {up }}^{-1}\right) \mathrm{D}^{-1}$, where $\mathrm{F}_{\text {mig }}$ is the number of upstream migrating fish, $\mathrm{F}_{\text {up }}$ is the number of fish that reached one of the most upstream receivers (receivers 1, 2, 5 or 6) and D is the distance (river $\mathrm{km}$ ) between receiver 13 and the most upstream receivers. Importantly, this analysis was only possible because the detection probability of fish passing receivers in the River Vidaa approached 100\%, consistent with previous studies (Aarestrup et al. 2014; 2015).

To test for correlations between 1) time at sea and timing of river entry (receiver 16), as well as 2) time at sea and timing of arrival at the putative spawning sites (receivers 1,2,5 or 6), least square linear regressions were employed. For this purpose, days spent at sea were regressed against river entry date and spawning site arrival date, respectively.

To estimate upstream migration speeds, the river was diverted into five sections: A, B, C, D and E (Jensen et al. 2018b) (Fig. 1). For the individual fish, the migration speed through each section was estimated using receiver locations (Fig. 1) and the fish detection data. Specifically, migration speeds were calculated using the distances $(\mathrm{m})$ between sequential receivers and the time (h) spent covering the distance. Following previous studies (Jensen et al. 2018b), these data were used to examine whether the two artificial lakes (Lake Nørresø and Lake Hestholm Kog; Fig. 1) affected upstream migration speeds. Migration speeds associated with the five river sections (A, B, C, D and E) were compared using generalized mixed effect models (GLMM) following Zuur et al. (2009). A model was fitted with migration speed as a function of length, fish ID and river section. To account for within-individual dependency, individual fish ID was included as a 
random factor (Moe et al. 2016), while river sections were included as a fixed factor. Fish body length was included in the model to correct for any correlation between individual body length and migration speed. (Baktoft et al. 2016). The significance of each section on migration speed was tested using the Likelihood ratio test based on maximum likelihood estimation (Aarestrup et al. 2015). The model was fitted by assuming Gamma distribution of data. Using residual plots as model diagnostics, no sign of violation of model assumptions was found.

To further assess the effects of artificial lakes, least square linear regression was used to correlate the time spent in the artificial lakes with arrival date in the spawning areas.

Least square linear regression was employed to examine effects of river temperature on migration speeds. The analyses were restricted to river sections that included a temperature logger. Specifically, the influence of temperature on migration speeds was examined between six receiver pairs: 14-13, 12-10, 10-9, 8-7, 7-6 and 7-5 (Fig. 1). The average water temperature logged while the individual fish passed between the receiver pairs was regressed against the associated migration speed.

Similarly, individual upstream migration speeds between 12 receivers, (receiver 13-1; Fig. 1) were used to examine whether migration speed is a repeatable trait in the North Sea houting. To this end, the intraclass correlation coefficient (ICC) was quantified using a linear mixed model and the restricted maximum likelihood procedure (Nakagawa and Schielzeth 2010). Specifically, measures of repeatability reveal the proportion of phenotypic variation that can be attributed to between-subject variation (Nakagawa and Schielzeth 2010). The model included migration speed as a function of fish body length to correct for any correlation between migration speed and body length among individuals (Baktoft et al. 2016).

Individual estimates of gill $\mathrm{Na}^{+} / \mathrm{K}^{+}$ATPase activity and blood osmolality were compared between the North Sea houting and anadromous and resident populations of European whitefish. To adjust for variation in body mass (g), data were regressed against individual body mass to estimate slope values. Slope values were subsequently compared between populations using analysis of covariance (ANCOVA) to test for differences in $\mathrm{Na}^{+} / \mathrm{K}^{+}$-ATPase activity and osmolality between the North Sea houting and anadromous and resident populations of European whitefish (Finley et al. 2016). Subsequently, post-hoc analyses based on the Holm-Šídák test were employed to identify differences. 
The statistical software R (R Development Core team 2016) was used for statistical analyses. Specifically, the analyses were based on the R-packages lme4 (Bates et al. 2014) and dunn.test (Dinno 2017). Results were considered significant at $P<0.05$. All values are reported as means \pm s.e.m. unless otherwise noted.

\section{RESULTS}

A total of 56 out of 78 tagged houting (72\%) entered the Wadden Sea after the spawning season in the winter of 2014-2015. Among the 56 fish, 36 individuals subsequently returned to the river, indicating a marine mortality approaching 36\%. The marine mortality did not appear to vary with fish body length (logistic regression, $P=0.28$ ). On average, North Sea houting spent $193 \pm 34$ days (range 72-291 days) in the Wadden Sea. The fish arrived at the river mouth between $2^{\text {nd }}$ July and $5^{\text {th }}$ November (median date: $14^{\text {th }}$ October), a period spanning 126 days. Most North Sea houting entered the river in October. Time spent at sea (i.e. days) was positively correlated with the river entry date $\left(\mathrm{R}^{2}=0.7, P<0.001\right)$, indicating that a long period at sea was associated with late river entry. A previous study indicated that some individual postspawning North Sea houting enter the Wadden Sea during the winter, whereas other North Sea houting enter the Wadden Sea in the spring (four months later; Jensen et al. 2018b). The present correlational analysis indicates that a late return to the river from the Wadden Sea is not just compensating for a late sea entry (e.g. in the spring), but instead allows the fish to spend a longer period in the marine environment.

Analyses indicated that the probability of river entry correlated negatively with water temperature (logistic regression; $P=0.009$ ). The highest probability of river entry occurred between 8 and $9^{\circ} \mathrm{C}$ (Fig. 2a). In contrast, the probability of river entry correlated positively with river discharge, indicating a higher probability of river entry at elevated river discharges (logistic regression; $P=0.042$ ) (Fig. 2b; Fig. 3).

Among the 36 fish that entered the river from the Wadden Sea, three individuals (8\%) remained in the estuarine area (receivers 16-13; Fig. 1), whereas 33 individuals (92\%) migrated further upstream (i.e. left receiver 13 in the upstream direction). 
Migrating individuals spent $49 \pm 8.5$ days (range 0.04 - 250 days) in the estuarine area (receivers 16 13; Fig. 1) before the upstream migration, including one individual that only briefly left the river in March 2015 and spent the remaining time in the estuarine area instead of the Wadden Sea.

Upstream migration from the estuarine area (i.e. upstream of receiver 13; Fig. 1) started between $17^{\text {th }}$ July and $23^{\text {rd }}$ November (median date $22^{\text {nd }}$ October). The majority of the fish $(85 \%)$ started the upstream migration in October.

During the upstream spawning migration, eight fish (24\%) were lost due to unknown circumstances, while $25(76 \%)$ of the 33 fish reached the most upstream receivers (i.e. receivers 1, 2, 5 or 6). This loss rate corresponds to a potential mortality of $1.1 \%$ mortality per $\mathrm{km}$. Three fish were lost in section C, corresponding to Lake Rudbøl and the lentic Magisterkogen, two fish were lost in section E, corresponding to the artificial Lake Nørresø, one fish was lost in section D, corresponding to the artificial Lake Hestholm Kog, one fish was lost in section A, corresponding to River Grønaa and finally one fish was lost after passing receiver no. 4 located upstream River Vidaa (Fig. 1).

The duration of the upstream migration (i.e. time between receiver 13 and receivers $1,2,5$ or 6 depending on migration route) was $41 \pm 6$ days (range 5-141 days). Fish arrived at the putative spawning areas between $31^{\text {st }}$ October and $23^{\text {rd }}$ January (median date $26^{\text {th }}$ November), but primarily during late November and early December.

Arrival date in spawning areas was not correlated with the time spent at sea (least square linear regression, $\mathrm{R}^{2}<0.0001, P>0.96$ ), indicating that a long period spent at sea did not result in late arrival in the spawning areas. Thus, there was no evidence of a trade-off between a long time spent at sea and early arrival in the spawning areas, presumably because early river entry was associated with a longer period of time spent in the estuarine area or slow upstream migration.

Analyses indicated that migration speeds differed between river sections (GLMM, L-ratio $=47.4, \mathrm{df}=$ 4, $P<0.001$ ) (Fig. 4; Fig. 1). Fastest migration speeds were observed in sections A, B and C, whereas significantly slower migration speeds were recorded in the sections with artificial lakes, i.e. sections D and E (Fig. 4). The slowest migration speeds were measured in section $\mathrm{E}(\mathrm{GLMM}$, Value $=28.5, \mathrm{SE}=7.63 \mathrm{df}=$ 107 , t-value $=3.7, P<0.001)$, corresponding to passage of the artificial Lake Nørresø followed by section D 
$($ GLMM, Value $=5.2, \mathrm{SE}=1.8, \mathrm{df}=107, \mathrm{t}$-value $=2.8, P<0.01)$, corresponding to passage of the artificial Lake Hestholm Kog (Fig. 1; Fig. 4).

Fish spent $13 \pm 2$ days (range 0.3 - 36 days) and $9 \pm 3$ (range 0.1-42 days) traversing Lake Nørresø and Lake Hestholm Kog, respectively. Time spent in the artificial lakes did not correlate with arrival date in the spawning areas (least square linear regression: $\mathrm{R}^{2}<0.057, P>0.25$ ), suggesting that a longer period of time spent in the artificial lakes was not associated with a late arrival time in the spawning areas.

Migration speeds correlated positively with water temperature, although the amount of variation explained was low (least square linear regression, $\mathrm{R}^{2}=0.052, P<0.01$ ).

Results from the repeatability analysis revealed no signs of subject based variance, according to the calculation of repeatability and a subsequent ANOVA analysis (linear mixed model, ICC = 0.004; ANOVA, $P=1$ ). This indicated that migrating individuals did not travel consistently at a certain limited speed range during the upstream migration, but rather exhibited intra-individual variation in migration speeds through the different river sections.

Fish body mass (g) did not correlate significantly with gill $\mathrm{Na}^{+} / \mathrm{K}^{+}$ATPase activity (ANCOVA, $P=$ 0.11 ) or osmolality (ANCOVA, $P=0.44$ ). Fish body mass was therefore left out of the subsequent analyses. Mean gill $\mathrm{Na}^{+} / \mathrm{K}^{+}$ATPase activity differed significantly between North Sea houting caught in River Vidaa and resident and anadromous European whitefish caught in Lake Ring and Ringkøbing Fjord, respectively (ANOVA, $P<0.007$ ) (Fig 5a). Significantly lower $\mathrm{Na}^{+} / \mathrm{K}^{+}$ATPase activity levels were found in the samples from the resident population of European whitefish compared to North Sea houting (Holm-Šídák, $P=0.009$ ) and anadromous European whitefish (Holm-Šídák, $P<0.006)$. No significant difference was found between the anadromous European whitefish and North Sea houting $(P>0.6)$ (Fig 5a). Mean osmolality differed significantly between North Sea houting and both resident and anadromous European whitefish (ANOVA, $P$ $<0.001)$. Specifically, the osmolality in the North Sea houting was significantly higher than both the anadromous (Holm-Š́ídák, $P<0.001)$ and the resident (Holm-Š́ídák, $P<0.008)$ European whitefish (Fig. 5b).

\section{DISCUSSION}


In this study, we describe the marine mortality of the North Sea houting in the Wadden Sea and the subsequent upstream migration towards the spawning areas in the River Vidaa; the last known location in the world where the North Sea houting is spawning successfully. The marine mortality was $36 \%$ and exceeded previous mortality estimates (Jepsen et al. 2012). River entry from the Wadden Sea varied with river temperature and discharge, whereas the upstream migration speed correlated positively with river temperature. Analyzing individuals, there was no evidence of repeatability in upstream migration speed. Upstream migration was associated with a loss of $24 \%$ of the North Sea houting, and migration speeds declined during passage of artificial lakes. In the post-spawning state, the physiology of North Sea houting differed from populations of European whitefish.

The North Sea houting is living in the Wadden Sea, an area recognized as a World Heritage Site, and the fish is protected by the Bern Convention and the EU Habitat Directive. Despite these measures, the River Vidaa population remains critically low with only 3,500 adult fish left (Svendsen et al. 2018). Numerous conservation and restoration projects have failed to recover populations in rivers where the North Sea houting thrived historically (Svendsen et al. 2018). Investigating mechanisms leading to mortality and loss prior to spawning and relationships with environmental factors is therefore important to improve further conservation planning.

We found that $36 \%$ of the North Sea houting did not return to the River Vidaa after entering the Wadden Sea. Although straying (Keefer and Caudill 2014; Thorstad et al. 2016) and non-consecutive repeat spawning behavior (Rideout et al. 2005; Jonsson and Jonsson 2009) cannot be ruled out, we assume that the marine loss corresponded largely to mortality. In a previous long term study, the total annual mortality of adult North Sea houting was estimated to be $20 \%$ (Jepsen et al. 2012). While the data provided by Jepsen et al. (2012) may be influenced by catch efficacy, our data could be influenced by irregular spawning behavior (e.g. straying). Studies on other salmonids (brown trout; S. trutta) have provided mortality estimates that vary substantially between years and locations (Jonsson and Jonsson 2009; Aldvén et al. 2015). Marine mortality may range between 15\% (Thorstad et al. 2016) and 70\% (Berg and Jonsson 1990; Aarestrup et al. 2015). Thus, the present marine mortality estimate (36\%) from one year and one location should be interpreted with caution. 
Marine mortality of salmonids is influenced by several factors (Sobocinski et al. 2018), including body size (Berg and Jonsson 1990; Jonsson and Jonsson 2009), timing of seaward migration (Jonsson and Jonsson 2009; 2014), feeding efficiency and growth (Kennedy et al. 2008; Henderson et al. 2018; Jensen et al. 2018a), environmental conditions (Gosselin et al. 2018) pathogens (Gargan et al. 2012; Gjelland et al. 2014; Skaala et al. 2014; Halttunen et al. 2018) as well as predation by birds (Dieperink et al. 2002; Wiese et al. 2008) and seals. Harbour seals (Phoca vitulina, Linnaeus 1758) are abundant in the Wadden Sea (Reijnders et al. 2010) and are growing in numbers in the area (Jensen et al. 2015a; Aarts et al. 2019). Seal density often correlate negatively with salmonid productivity (Nelson et al. 2018) and seals may threaten salmonid species (Wright et al. 2007; Thomas et al. 2017). The marine migration of the North Sea houting remains to be mapped, and future studies should determine the specific factors that drive the mortality after the fish enter the Wadden Sea. Identifying mechanisms leading to marine mortality could be used to reduce the overall annual mortality of North Sea houting.

The total annual mortality of adult North Sea houting may also be influenced by the mortality in freshwater, especially during spawning (autumn) and post-spawning (spring) migrations. In the present study, eight adults (24\%) were lost during the upstream migration, suggesting a mortality of $1.1 \%$ per $\mathrm{km}$ in the autumn. A previous study on the post-spawning individuals in freshwater suggested a slightly higher mortality of $1.4 \%$ per km in the spring (Jensen et al. 2018b). At least $30 \%$ of the loss (i.e. six adults) in the post-spawning state (i.e. spring) was inflicted by foraging cormorants (Phalacrocorax carbo, Linnaeus, 1758) (Jensen et al. 2018b). In the present autumn study, we were unable to determine the factors that induced the loss of the adults during the upstream migration. However, a marine mortality of $36 \%$, combined with spring and autumn mortalities approaching $26 \%$ and $24 \%$, respectively, in freshwater indicate that the annual mortality may be significantly higher than previously thought; warranting further studies that determine the factors that cause the mortality in freshwater and marine environments. The present mortality estimates are only valid for adult fish. The mortality of the juvenile fish is likely much higher.

On average, adult North Sea houting spent 193 days (range 72 - 291 days) in the Wadden Sea before returning to River Vidaa. In anadromous salmonids, it is well known that some individuals may return to the natal river many months prior to spawning (Quinn et al. 2016). An average of 193 days at sea is a longer 
period of time than observed in a range of studies on other adult anadromous salmonids. In brown trout for example, the period spent at sea rarely approaches 193 days and typically ranges between $54-88$ days (Berg and Berg 1989), 89-145 days (Bendall et al. 2005) and 78-191 days (Aarestrup et al. 2015). The period spent at sea is likely governed by latitude (Jonsson et al. 2007; Aarestrup et al. 2015), temperature (Berg and Berg 1989), difficult access to the river (Berg and Jonsson 1990), riverine competition for spawning areas and trade-offs involving growth and mortality rates in the marine and freshwater environments (Quinn et al. 2016). We suggest that the environmental conditions in the River Vidaa and the Wadden Sea favor a tradeoff between growth and mortality where fish are spending a prolonged period of time at sea to recover energy reserves (Olsen et al. 2006) and maximize somatic growth (Brönmark et al. 2008) while facing relatively limited mortality risk.

North Sea houting river entry varied with environmental factors. Specifically, river entry peaked at increasing river discharges and at temperatures $<10^{\circ} \mathrm{C}$. Salmonid upstream migration at increasing river discharges is commonly observed (Svendsen et al. 2004; Mitchell and Cunjak 2007; Bendall et al. 2012), although more complex patterns have also been reported (Jonsson et al. 2007). River entry at temperatures < $10^{\circ} \mathrm{C}$ is relatively cold compared to a number of previous studies $\left(12-16^{\circ} \mathrm{C}\right.$ (Borcherding et al. 2014); 10 $15^{\circ} \mathrm{C}$ Jonsson et al. (2007)), but similar to brown trout $>30 \mathrm{~cm}$ in the River Imsa in southern Norway (Jonsson and Jonsson 2002). Our study suggests that North Sea houting river entry could be sensitive to factors that change river discharge or temperature. This could be important because changed timing of river entry may expose salmonids to elevated mortality (Berg and Jonsson 1990).

The upstream migration speed decreased when the fish traversed two artificial lakes. Decreased migration speeds were also observed when the fish traversed the artificial lakes in the downstream direction (Jensen et al. 2018b). The underpinning mechanisms are unknown but could be related to navigation through the lakes. In a recent study on brown trout passing a lake, Schwinn et al. (2017) suggested that migration speed is controlled by complex interactions between several factors, including turbidity, wind-induced currents and lake morphology that may affect navigation. Reduced migration speed through a reservoir may lead to increased mortality due to predation for example by cormorants (Jepsen et al. 1998; Olsson et al. 
2001). In the present study, North Sea houting were lost in both artificial lakes, but the impacts on the population size are unknown.

Reduced upstream migration speeds through the artificial lakes could eventually delay spawning activities further upstream. Previous studies have reported that forced delays of spawning often reduce egg survival because of excessive egg ageing after ovulation (Gaudemar and Beall 1998; Samarin et al. 2015). It is well known that migratory delays can have severe negative consequences (Svendsen et al. 2011; Crozier et al. 2017; Schwinn et al. 2018); however, we found no correlation between the times spent traversing the artificial lakes and subsequent arrival dates in the spawning areas, suggesting that the reduced migration speeds through the lakes did not translate into delayed spawning.

The importance of behavioral phenotypes is increasingly recognized in conservation planning (Killen et al. 2016; Hirsch et al. 2017; Merrick and Koprowski 2017; Meager et al. 2018). A previous study revealed that circadian activity patterns are repeatable in North Sea houting, indicating that individual fish exhibit behavioral phenotypes in relation to migration activity through the diel $24 \mathrm{~h}$ period (Jensen et al. 2018b). In the present study we tested if individual fish exhibit behavioral phenotypes in relation to upstream migration speed. Unlike previous field studies (Hanson et al. 2008; Taylor and Cooke 2014; Baktoft et al. 2016), we found no evidence that upstream migration speeds are repeatable in individual fish. Behavioral field studies conducted over several months may provide data that are influenced by environmental conditions (Svendsen et al. 2004; Salinger and Anderson 2006; Bendall et al. 2012) and therefore more variable and less repeatable. We suggest future repeatability studies account for variable environmental conditions and include individual responses to changes in river discharge and temperature.

Our data revealed a positive relationship between water temperature and upstream migration speed, suggesting that North Sea houting were often migrating at temperatures below the optimum temperature (Salinger and Anderson 2006). It seems paradoxical that river entry correlated negatively with temperature, whereas upstream migration speed correlated positively with river temperature. If the fish had entered the river earlier (e.g. during the summer), river temperatures would have been warmer and upstream migration could have progressed faster. We suggest that the negative relationship between water temperature and river entry reflects fish that are extending the period of time spent foraging in the marine environment and 
therefore tend to enter the river in relatively cold water. Due to the resulting cold conditions in the river, fish end up migrating at river temperatures below the optimum temperature and make relatively slow progress towards the spawning areas. This potential trade-off between time spent foraging in the marine environment and time spent reaching the spawning areas warrants further study.

On average, the upstream migrating North Sea houting spent 49 days in the estuarine area before proceeding further upstream. Similar observations were made in the post-spawning state when fish utilized the estuarine area prior to entering the Wadden Sea (Jensen et al. 2018b). It is therefore likely that the estuarine area represents an important habitat for North Sea houting. Therefore, it may be important to protect or restore estuarine areas in River Vidaa and in other rivers where the goal is to establish viable North Sea houting populations.

The North Sea houting is closely related to the European whitefish, but the North Sea houting has a better capacity to tolerate high salinity. The European whitefish is unable to tolerate full marine salinities (> 30\%o) (Madsen et al. 1996), whereas the North Sea houting live in the Wadden Sea for several months, where such conditions occur frequently (Jensen et al. 2015b). In an attempt to address recent requests for applying physiological measures in conservation research (Mckenzie et al. 2016; Mahoney et al. 2018), we analysed gill $\mathrm{Na}^{+} / \mathrm{K}^{+}$ATPase activity and blood osmolality in North Sea houting and resident and anadromous populations of European whitefish in the post-spawning state. Consistent with our hypothesis, $\mathrm{Na}^{+} / \mathrm{K}^{+}$ATPase activity was elevated in post-spawning freshwater North Sea houting before they returned to the Wadden Sea, in comparison with the freshwater resident European whitefish situated in freshwater. This suggests a degree of pre-adaptation to the hypo-osmoregulatory state before returning to the marine environment in the North Sea houting. However, the anadromous whitefish caught in brackish water in the Ringkøbing Fjord had gill $\mathrm{Na}^{+} / \mathrm{K}^{+}$ATPase levels in the same range as post-spawning houting in freshwater and elevated compared to resident whitefish in freshwater. This supports previous findings that whitefish increase gill $\mathrm{Na}^{+} / \mathrm{K}^{+}$ATPase activity upon exposure to elevated salinity (Madsen et al., 1996). Blood osmolality was consistently higher in North Sea houting than both anadromous and resident whitefish populations (caught in brackish and freshwater environments, respectively), suggesting that the North Sea houting deviate physiologically from populations of European whitefish. Our study is the first to compare 
physiological traits in North Sea houting and European whitefish. Common garden experiments are required to reveal if the North Sea houting exhibits adaptations to the local environment, similar to other salmonid populations (Jensen et al. 2008). Assessing the value of habitats for endangered species often requires physiological knowledge, in particular for anadromous species. Although the present physiological data cannot be used directly in management, the data do suggest that North Sea houting and European whitefish differ in physiologically at least in terms of osmoregulation. These findings indicate that data on European whitefish may not be directly applicable for North Sea houting.

\section{ACKNOWLEDGEMENTS}

We thank Michael G. Deacon, Hans-Jørn A. Christensen and Jes Dolby for technical assistance and the Fisheries and Maritime Museum in Esbjerg for logistical support. Moreover, we thank Dr. Ingebrigt Uglem, Norwegian Institute for Nature Research, and the Ocean Tracking Network for providing access to acoustic receivers. Finally, we thank Tønder Municipality for access to river discharge data. The study was financially supported by the 15. Juni Foundation (grant number 2014-A-22), the Wadden Sea National Park and Aalborg Zoo Conservation Foundation. J.C.S. received support from the Foundation for Science and Technology (FCT) in Portugal [SFRH/BPD/89473/2012]. SSM was supported by a grant from the Danish Research Council for Independent Research (DFF-4181-00020).

References

Aarestrup, K., Baktoft, H., Koed, A., Del Villar-Guerra, D., and Thorstad, E.B. 2014. Comparison of the riverine and early marine migration behaviour and survival of wild and hatchery-reared sea trout Salmo trutta smolts. Mar. Ecol. Prog. Ser. 496: 197-206. doi:10.3354/meps10614.

Aarestrup, K., Baktoft, H., Thorstad, E., Svendsen, J., Höjesjö, J., and Koed, A. 2015. Survival and progression rates of anadromous brown trout kelts Salmo trutta during downstream migration in freshwater and at sea. Mar. Ecol. Prog. Ser. 535(October): 185-195. doi:10.3354/meps11407.

Aarestrup, K., and Jepsen, N. 1998. Spawning migration of sea trout ( Salmo trutta ( L )) in a Danish river. Hydrobiologia, 371/372(L): 275-281. doi:10.1023/A.

Aarestrup, K., and Koed, A. 2003. Survival of migrating sea trout (Salmo trutta) and Atlantic salmon (Salmo salar) smolts negotiating weirs in small Danish rivers. Ecol. Freshw. Fish, 12(3): 169-176. doi:10.1034/j.1600-0633.2003.00027.x.

Aarestrup, K., Nielsen, C., and Madsen, S.S. 2000. Relationship between gill $\mathrm{Na}{ }^{+}, \mathrm{K}+-\mathrm{ATPase}$ activity and 
downstream movement in domesticated and first-generation offspring of wild anadromous brown trout (Salmo trutta). Can. J. Fish. Aquat. Sci. 57(10): 2086-2095. doi:10.1139/cjfas-57-10-2086.

Aarts, G., Brasseur, S., Poos, J.J., Schop, J., Kirkwood, R., van Kooten, T., Mul, E., Reijnders, P., Rijnsdorp, A.D., and Tulp, I. 2019. Top-down pressure on a coastal ecosystem by harbor seals. Ecosphere, 10(1): e02538. doi:10.1002/ecs2.2538.

Aldvén, D., Hedger, R., Økland, F., Rivinoja, P., and Höjesjö, J. 2015. Migration speed, routes, and mortality rates of anadromous brown trout Salmo trutta during outward migration through a complex coastal habitat. Mar. Ecol. Prog. Ser. 541(March): 151-163. doi:10.3354/meps11535.

Armstrong, J.D., McKelvey, S., Smith, G.W., Rycroft, P., and Fryer, R.J. 2018. Effects of individual variation in length, condition and run-time on return rates of wild-reared Atlantic salmon Salmo salar smolts. J. Fish Biol. 92(3): 569-578. doi:10.1111/jfb.13548.

Baktoft, H., Jacobsen, L., Skov, C., Koed, A., Jepsen, N., Berg, S., Boel, M., Aarestrup, K., and Svendsen, J.C. 2016. Phenotypic variation in metabolism and morphology correlating with animal swimming activity in the wild: Relevance for the OCLTT (oxygen- and capacity-limitation of thermal tolerance), allocation and performance models. Conserv. Physiol. 4(1): 1-14. doi:10.1093/conphys/cov055.

Bates, D., Mächler, M., Bolker, B., and Walker, S. 2014. Fitting Linear Mixed-Effects Models using lme4. eprint arXiv:1406.5823 67(1): 51. doi:10.18637/jss.v067.i01.

Bendall, B., Moore, A., Maxwell, D., Davison, P., Edmonds, N., Archer, D., Solomon, D., Greest, V., Wyatt, R., and Broad, K. 2012. Modelling the migratory behaviour of salmonids relation to environmental and physiological parameters using telemetry data. Fish. Manag. Ecol. 19(6): 475-483. doi:10.1111/j.13652400.2011.00811.x.

Bendall, L.B., Moore A N, A., and Quayle, D. V. 2005. The post-spawning movements of migratory brown trout Salmo trutta L. J. Fish Biol. 67: 809-822. doi:10.1111/j.1095-8649.2005.00786.x.

Berg, O.K., and Berg, M. 1989. The duration of sea and freshwater residence of the sea trout, Salmo trutta, from the Vardnes River in northern Norway. Environ. Biol. Fishes, 24(1): 23-32. doi:10.1007/BF00001607.

Berg, O.K., and Jonsson, B. 1990. Growth and survival rates of the anadromous trout, Salmo trutta, from the Vardnes River, northern Norway. Environ. Biol. Fishes, 29(2): 145-154. doi:10.1007/BF00005031.

Boel, M., Aarestrup, K., Baktoft, H., Larsen, T., Søndergaard Madsen, S., Malte, H., Skov, C., Svendsen, J.C., and Koed, A. 2014. The physiological basis of the migration continuum in brown trout (Salmo trutta). Physiol. Biochem. Zool. 87(2): 334-345. doi:10.1086/674869.

Bohlin, T., Pettersson, J., and Degerman, E. 2001. Population density of migratory and resident brown trout (Salmo trutta) in relation to altitude: Evidence for a migration cost. J. Anim. Ecol. 70(1): 112-121. doi:10.1046/j.1365-2656.2001.00466.x.

Borcherding, J., Breukelaar, A.W., Winter, H. V., and König, U. 2014. Spawning migration and larval drift of anadromous North Sea houting (Coregonus oxyrinchus) in the River IJssel, the Netherlands. Ecol. Freshw. Fish, 23(2): 161-170. doi:10.1111/eff.12058.

Borcherding, J., Heynen, M., Jäger-Kleinicke, T., Winter, T., and Eckmann, R. 2010. Re- establishment of the North Sea houting in the River Rhine. Fish. Manag. Ecol. 17(3): 291-293. doi:https://dx.doi.org/10.1111/j.1365-2400.2009.00710.x.

Braithwaite, V.A., and Girvan, J.R. 2003. Use of water flow direction to provide spatial information in a small-scale orientation task. J. Fish Biol. 63: 74-83. doi:10.1111/j.1095-8649.2003.00218.x.

Brönmark, C., Skov, C., Brodersen, J., Nilsson, P.A., and Hansson, L. 2008. Seasonal Migration Determined by a Trade-Off between Predator Avoidance and Growth. PLoS One, 3(4): e1957. doi:10.1371/journal.pone.0001957.

Brown, R.S., Harnish, R.A., Carter, K.M., Boyd, J.W., Deters, K.A., and Eppard, M.B. 2010. An Evaluation of the Maximum Tag Burden for Implantation of Acoustic Transmitters in Juvenile Chinook Salmon. North Am. J. Fish. Manag. 30(2): 499-505. doi:10.1577/M09-038.1.

Chapman, B.B., Hulthén, K., Blomqvist, D.R., Hansson, L.A., Nilsson, J.Å., Brodersen, J., Anders Nilsson, P., Skov, C., and Brönmark, C. 2011. To boldly go: individual differences in boldness influence migratory tendency. Ecol. Lett. 14(9): 871-876. doi:10.1111/j.1461-0248.2011.01648.x. 
Christensen I.G. and Hvidt C.B. 1990. Taksonomisk placering af nordsøsnæbel (Coregonus oxyrhinchus L.) fra Vidaa-systemet i relation til helt (Coregonus lavaretus L.) fra Skjern aa. M.Sc. Thesis, Institute of Biology, Department of Ecology and Genetics, University of Aarhus

Connors, K.B., Scruton, D., Brown, J.A., and McKinley, R.S. 2002. The effects of surgically-implanted dummy radio transmitters on the behaviour of wild Atlantic salmon smolts. Hydrobiologia, 483 (1-3): 231-237. doi:10.1023/A:1021304301403.

Crozier, L.G., Bowerman, T.E., Burke, B.J., Keefer, M.L., and Caudill, C.C. 2017. High-stakes steeplechase: a behavior-based model to predict individual travel times through diverse migration segments. Ecosphere, 8(10): 1-25. doi:10.1002/ecs2.1965.

Dieperink, C., Bak, B.D., Pedersen, L.-F., Pedersen, M.I., and Pedersen, S. 2002. Predation on Atlantic salmon and sea trout during their first days as postsmolts. J. Fish Biol. 61(3): 848-852. doi:10.1006/jfbi.2002.2090.

Dinno, A. 2017. Package 'dunn.test.' CRAN Repos. doi:10.1287/mnsc.30.10.1250.

Ebner, B.C., and Thiem, J.D. 2009. Monitoring by telemetry reveals differences in movement and survival following hatchery or wild rearing of an endangered fish. Mar. Freshw. Res. 60(1): 45-57. doi:10.1071/MF08027.

Eggeman, S.L., Hebblewhite, M., Bohm, H., Whittington, J., and Merrill, E.H. 2016. Behavioural flexibility in migratory behaviour in a long-lived large herbivore. J. Anim. Ecol. 85(3): 785-797. doi:10.1111/1365-2656.12495.

Etheridge, E.C., Adams, C.E., Bean, C.W., Durie, N.C., Gowans, A.R.D., Harrod C., et al. 2012. Are phenotypic traits useful for differentiating among a priori Coregonus taxa? J. Fish Biol. 80(2): 387407. doi:10.1111/j.1095-8649.2011.03189.x.

Finley, M.L.D., Kidd, K.A., Curry, R.A., Lescord, G.L., Clayden, M.G., and O’Driscoll, N.J. 2016. A Comparison of Mercury Biomagnification through Lacustrine Food Webs Supporting Brook Trout (Salvelinus fontinalis) and Other Salmonid Fishes. Front. Environ. Sci. 4(April): 1-13. doi:10.3389/fenvs.2016.00023.

Forseth, T., Næsje, T.F., Jonsson, B., and Hårsaker, K. 1999. Juvenile migration in brown trout: a consequence of energetic state. J. Anim. Ecol. 68(4): 783-793. doi:10.1046/j.1365-2656.1999.00329.x.

Freyhof, J., and Schöter, C. 2005. The houting Coregonus oxyrinchus (L.) (Salmoniformes: Coregonidae), a globally extinct species from the North Sea basin. J. Fish Biol. 67(3): 713-729. doi:10.1111/J.10958649.2005.00771.X.

Gargan, P.G., Forde, G., Hazon, N., Russell, D.J.F., Todd, C.D., and Grant, J.W.A. 2012. Evidence for sea lice-induced marine mortality of Atlantic salmon ( Salmo salar ) in western Ireland from experimental releases of ranched smolts treated with emamectin benzoate. Can. J. Fish. Aquat. Sci. 69(2): 343-353. doi:10.1139/f2011-155.

Gaudemar, B., and Beall, E. 1998. Effects of overripening on spawning behaviour and reproductive success of Atlantic salmon females spawning in. J. Fish Biol. 33: 434-446. doi:10.1111/j.10958649.1998.tb00991.x.

Gjelland, K.Ø., Serra-Llinares, R.M., Hedger, R.D., Arechavala-Lopez, P., Nilsen, R., Finstad B., et al. 2014. Effects of salmon lice infection on the behaviour of sea trout in the marine phase. Aquacult. Environ. Interact. 5(3): 221-233. doi:10.3354/aei00105.

Gosselin, J.L., Zabel, R.W., Anderson, J.J., Faulkner, J.R., Baptista, A.M., and Sandford, B.P. 2018. Conservation planning for freshwater-marine carryover effects on Chinook salmon survival. Ecol. Evol. 8(1): 319-332. doi:10.1002/ece3.3663.

Gowans, A.R.D., Armstrong, J.D., Priede, I.G., and McKelvey, S. 2003. Movement of Atlantic Salmon migrating upstream through a fish passage complex in Scotland. Ecol. Freshw. Fish, 12(3): 177-189. doi:10.1034/j.1600-0633.2003.00018.x.

Halttunen, E., Gjelland, K., Hamel, S., Serra-Llinares, R.M., Nilsen, R., Arechavala-Lopez, P., Skarðhamar, J., Johnsen, I.A., Asplin, L., Karlsen, Ø., Bjørn, P.-A., and Finstad, B. 2018. Sea trout adapt their migratory behaviour in response to high salmon lice concentrations. J. Fish Dis. 41(6): 953-967. doi:10.1111/jfd.12749.

Hanson, K.C., Cooke, S.J., Hinch, S.G., Crossin, G.T., Patterson, D. A, English, K.K., et al. 2008. Individual variation in migration speed of upriver-migrating sockeye salmon in the Fraser River in relation to their 
physiological and energetic status at marine approach. Physiol. Biochem. Zool. 81(3): 255-268. doi:10.1086/529460.

Hasselquist, D., Montràs-Janer, T., Tarka, M., and Hansson, B. 2017. Individual consistency of long-distance migration in a songbird: significant repeatability of autumn route, stopovers and wintering sites but not in timing of migration. J. Avian Biol. 48(1): 91-102. doi:10.1111/jav.01292.

Henderson, M.J., Fiechter, J., Huff, D.D., and Wells, B.K. 2018. Spatial variability in ocean-mediated growth potential is linked to central California Chinook salmon survival. Fish. Oceanogr. 28(1): 334344. doi:10.1111/fog. 12415.

Hewson, C.M., Thorup, K., Pearce-Higgins, J.W., and Atkinson, P.W. 2016. Population decline is linked to migration route in the Common Cuckoo. Nat. Commun. 7: 12296. doi:10.1038/ncomms12296.

Hirsch, P.E., Thorlacius, M., Brodin, T., and Burkhardt-Holm, P. 2017. An approach to incorporate individual personality in modeling fish dispersal across in-stream barriers. Ecol. Evol. 7(2): 720-732. doi:10.1002/ece3.2629.

Hulthén, K., Chapman, B.B., Nilsson, P.A., Hansson, L.A., Skov, C., Brodersen, J., Vinterstare, J., and Brönmark, C. 2017. A predation cost to bold fish in the wild. Sci. Rep. 7(1): 1-5. doi:10.1038/s41598017-01270-w.

Jacobsen, M.W., Hansen, M.M., Orlando, L., Bekkevold, D., Bernatchez, L., Willerslev, E., and Gilbert, M.T.P. 2012. Mitogenome sequencing reveals shallow evolutionary histories and recent divergence time between morphologically and ecologically distinct European whitefish (Coregonus spp.). Mol. Ecol. 21(11): 2727-2742. doi:10.1111/j.1365-294X.2012.05561.x.

Jensen, A.J., Finstad, B., and Fiske, P. 2018a. Evidence for the linkage of survival of anadromous Arctic char and brown trout during winter to marine growth during the previous summer. Can. J. Fish. Aquat. Sci. 75(7485): 663-672. doi:10.1139/cjfas-2017-0077.

Jensen, L.F., Galatius, A., and Teilmann, J. 2015a. First report on a newborn grey seal pup (Halichoerus grypus) in the Danish Wadden Sea since the 16th Century. doi:10.1017/S1755267215001062.

Jensen, L.F., Hansen, M.M., Pertoldi, C., Holdensgaard, G., Mensberg, K.L.D., and Loeschcke, V. 2008. Local adaptation in brown trout early life-history traits: implications for climate change adaptability. Proc. R. Soc. B Biol. Sci. 275(1653): 2859-2868. doi:10.1098/rspb.2008.0870.

Jensen, L.F., Rognon, P., Aarestrup, K., Bøttcher, J.W., Pertoldi, C., Thomsen, S.N., Hertz, M., Winde, J., and Svendsen, J.C. 2018b. Evidence of cormorant-induced mortality, disparate migration strategies and repeatable circadian rhythm in the endangered North Sea houting (Coregonus oxyrinchus): a telemetry study mapping the postspawning migration. Ecol. Freshw. Fish, 27(3): 672-685. doi:10.1111/eff.12383.

Jensen, L.F., Thomsen, D.S., Madsen, S.S., Ejbye-Ernst, M., Poulsen, S.B., and Svendsen, J.C. $2015 b$. Development of salinity tolerance in the endangered anadromous North Sea houting Coregonus oxyrinchus: implications for conservation measures. Endanger. Species Res. 28(2): 175-186. doi:10.3354/esr00692.

Jepsen, N., and Aarestrup, K. 1999. A comparison of the growth of radio-tagged and dye-marked pike. J. Fish Biol. 55(4): 880-883. doi:10.1006/jfbi.1999.1032.

Jepsen, N., Aarestrup, K., Økland, F., and Rasmussen, G. 1998. Survival of radio-tagged Atlantic salmon (Salmo salar L.) and trout (Salmo trutta L.) smolts passing a reservoir during seaward migration. Hydrobiologia, 371/372(August): 347-353. doi:10.1007/978-94-011-5090-3.

Jepsen, N., Deacon, M., and Koed, A. 2012. Decline of the North Sea houting: and protective measures for an endangered anadromous fish. Endanger. Species Res. 16(1): 77-84. doi:10.3354/esr00386.

Jonsson, B., and Jonsson, N. 2009. Migratory timing, marine survival and growth of anadromous brown trout Salmo trutta in the River Imsa, Norway. J. Fish Biol. 74(3): 621-638. doi:10.1111/j.10958649.2008.02152.x.

Jonsson, B., Jonsson, N., and Hansen, L.P. 2007. Factors affecting river entry of adult Atlantic salmon in a small river. J. Fish Biol. 71(4): 943-956. doi:10.1111/j.1095-8649.2007.01555.x.

Jonsson, N., and Jonsson, B. 2002. Migration of anadromous brown trout Salmo trutta in a Norwegian river. Freshw. Biol. 47(8): 1391-1401. doi:10.1046/j.1365-2427.2002.00873.x.

Jonsson, N., and Jonsson, B. 2014. Time and size at seaward migration influence the sea survival of Salmo salar. J. Fish Biol. 84(5): 1457-1473. doi:10.1111/jfb.12370. 
Kahler, T., Roni, P., and Quinn, T. 2001. Summer movement and growth of juvenile anadromous salmonids in small western Washington streams. Can. J. Fish. Aquat. Sci. 58(10): 1947-1956. doi:10.1139/cjfas58-10-1947.

Keefer, M.L., and Caudill, C.C. 2014. Homing and straying by anadromous salmonids: A review of mechanisms and rates. Rev. Fish Biol. Fish. 24(1): 333-368. doi:10.1007/s11160-013-9334-6.

Kennedy, B.P., Nislow, K.H., and Folt, C.L. 2008. Habitat-Mediated Foraging Limitations Drive Survival Bottlenecks for Juvenile Salmon. Ecology, 89(9): 2529-2541. doi:10.1890/06-1353.1.

Killen, S.S., Adriaenssens, B., Marras, S., Claireaux, G., and Cooke, S.J. 2016. Context dependency of trait repeatability and its relevance for management and conservation of fish populations. Conserv. Physiol. 4(1). doi:10.1093/conphys/cow007.

Koed, A., Baktoft, H., and Bak, B.D. 2006. Causes of mortality of Atlantic salmon (Salmo salar) and brown trout (Salmo trutta) smolts in a restored river and its estuary. River Res. Appl. 22(1): 69-78. doi:10.1002/rra.894.

Koed, A., and Thorstad, E.B. 2001. Long-term effect of radio-tagging on the swimming performance of pikeperch. J. Fish Biol. 58(6): 1753-1756. doi:10.1006/jfbi.2001.1582.

Kristensen, L.D., Støttrup, J.G., Svendsen, J.C., Stenberg, C., Højbjerg Hansen, O.K., and Grønkjær, P. 2017. Behavioural changes of Atlantic cod (Gadus morhua) after marine boulder reef restoration: implications for coastal habitat management and Natura 2000 areas. Fish. Manage. Ecol. 24(5): 353360. doi:10.1111/fme.12235.

Madsen, S.S., Larsen, B.K., and Jensen, F.B. 1996. Effects of freshwater to seawater transfer on osmoregulation, acid-base balance and respiration in river migrating whitefish (Coregonus lavaretus). J. Comp. Physiol. B, 166(2): 101-109. doi:10.1007/BF00301173.

Mahoney, J.L., Klug, P.E., and Reed, W.L. 2018. An assessment of the US endangered species act recovery plans: using physiology to support conservation. Conserv. Physiol. 6(1): 1-10. doi:10.1093/conphys/coy036.

Mccormick, S.D. 1993. Methods for non biopsy and measurement of $\mathrm{Na}^{+}, \mathrm{K}^{+}$-ATPase activity. Can. J. Aquat. Sci. 50(3):656-658. doi:10.1139/f93-075.

McCormick, S.D., and Björnsson, B.T. 1994. Physiological and hormonal differences among Atlantic salmon parr and smolts reared in the wild, and hatchery smolts. Aquaculture 121: 235-244.

McCormick, S.D., Saunders, R.L., and MacIntyre, A.D. 1989. Mitochondrial enzyme and Na+, K+-ATPase activity, and ion regulation during parr-smolt transformation of Atlantic salmon (Salmon salar). Fish Physiol. Biochem. 6(4): 231-241. doi:10.1007/BF01875026.

Mckenzie, D.J., Axelsson, M., Chabot, D., Claireaux, G., Cooke, S.J., Corner, R.A., et al. 2016. Conservation physiology of marine fishes: state of the art and prospects for policy. Conserv. Physiol. 4(1). doi:10.1093/conphys/cow046.

Meager, J.J., Fernö, A., and Skjæraasen, J.E. 2018. The behavioural diversity of Atlantic cod: insights into variability within and between individuals. Rev. Fish Biol. Fish. 28(1): 153-176. doi:10.1007/s11160017-9505-y.

Merrick, M.J., and Koprowski, J.L. 2017. Should we consider individual behavior differences in applied wildlife conservation studies? Biol. Conserv. 209(May): 34-44. doi:10.1016/j.biocon.2017.01.021.

Mitchell, S.C., and Cunjak, R. a. 2007. Relationship of upstream migrating adult Atlantic salmon ( Salmo salar ) and stream discharge within Catamaran Brook, New Brunswick. Can. J. Fish. Aquat. Sci. 64(3): 563-573. doi:10.1139/f07-032.

Moe, K., Næsje, T., Haugen, T., Ulvan, E., Aronsen, T., Sandnes, T., and Thorstad, E. 2016. Area use and movement patterns of wild and escaped farmed Atlantic salmon before and during spawning in a large Norwegian river. Aquacult. Environ. Interact. 8: 77-88. doi:10.3354/aei00165.

Moore, A., Potter, E.C.E., Milner, N.J., and Bamber, S. 1995. The migratory behaviour of wild Atlantic salmon ( Salmo salar ) smolts in the estuary of the River Conwy, North Wales. Can. J. Fish. Aquat. Sci. 52(9): 1923-1935. doi:10.1139/f95-784.

Nakagawa, S., and Schielzeth, H. 2010. Repeatability for Gaussian and non-Gaussian data: a practical guide for biologists. Biol. Rev.Camb. Philos. Soc. 85(August): 935-956. doi:10.1111/j.1469185X.2010.00141.x.

Nelson, B.W., Walters, C.J., Trites, A.W., and McAllister, M.K. 2018. Wild Chinook salmon productivity is 
negatively related to seal density and not related to hatchery releases in the Pacific Northwest. Can. J. Fish. Aquat. Sci. 16(June): 1-16. doi:10.1139/cjfas-2017-0481.

Nielsen, C., Aarestrup, K., Nørum, U., and Madsen, S.S. 2004. Future migratory behaviour predicted from premigratory levels of gill $\mathrm{Na}+/ \mathrm{K}+$-ATPase activity in individual wild brown trout (Salmo trutta). J. Exp. Biol. 207: 527-533. doi:10.1242/jeb.00783.

Olsen, E.M., Knutsen, H., Simonsen, J.H., Jonsson, B., and Knutsen, J.A. 2006. Seasonal variation in marine growth of sea trout, Salmo trutta, in coastal Skagerrak. Ecol. Freshw. Fish 15(4): 446-452. doi:10.1111/j.1600-0633.2006.00176.x.

Olsson, I.C., Greenberg, L.A., and Eklöv, A.G. 2001. Effect of an artificial pond on migrating brown trout smolts. N. Am. J. Fish. Manage. 21(3): 498-506. doi:10.1577/15488675(2001)021<0498:EOAAPO >2.0.CO;2.

Østbye, K., Amundsen, P.A., Bernatchez, L., Klemetsen, A., Knudsen, R., Kristoffersen, R., Næsje, T.F., and Hindar, K. 2006. Parallel evolution of ecomorphological traits in the European whitefish Coregonus lavaretus (L.) species complex during postglacial times. Mol. Ecol. 15(13): 3983-4001. doi:10.1111/j.1365-294X.2006.03062.x.

Østbye, K., Bernatchez, L., Næsje, T.F., Himberg, K.J.M., and Hindar, K. 2005. Evolutionary history of the European whitefish Coregonus lavaretus (L.) species complex as inferred from mtDNA phylogeography and gill-raker numbers. Mol. Ecol. 14(14): 4371-4387. doi:10.1111/j.1365294X.2005.02737.x.

Ovesen, N.B., Iversen, H.L., Larsen, S.E., Müller-Wohlfeil, D.-I., Svendsen, L.M., Blicher, A.S., and Jensen, P.M. 2000. Afstrømningsforhold i danske vandløb. Faglig rapport fra DMU nr. 340.

Pihl, S., and Laursen, K. 2002. Kortlægning af arter omfattet af EF-Habitatdirektivet 1997-2000. Rapport Nr. 167. Danmarks Miljøundersøgelser.

Piironen, J., Kiiskinen, P., Huuskonen, H., Heikura-Ovaskainen, M., and Vornanen, M. 2013. Comparison of Smoltification in Atlantic Salmon ( Salmo salar ) from Anadromous and Landlocked Populations Under Common Garden Conditions. Ann. Zool. Fennici 50(1-2): 1-15. doi:10.5735/086.050.0101.

Piper, A.T., Svendsen, J.C., Wright, R.M., and Kemp, P.S. 2017. Movement patterns of seaward migrating European eel (Anguilla anguilla) at a complex of riverine barriers: implications for conservation. Ecol. Freshw. Fish, 26: 87-98. doi:10.1111/eff.12257.

Poulsen, S.B., Jensen, L.F., Schulz, C., Deacon, M., Meyer, K.E., Jäger-Kleinicke, T., Schwarten, H., and Svendsen, J.C. 2012. Ontogenetic differentiation of swimming performance and behaviour in relation to habitat availability in the endangered North Sea houting (Coregonus oxyrinchus). Aquat. Living Resour. 25: 241-249. doi:10.1051/alr/2002019.

Quinn, T.P., McGinnity, P., Reed, T.E., and Bradford, M. 2016. The paradox of "premature migration" by adult anadromous salmonid fishes: patterns and hypotheses. Can. J. Fish. Aquat. Sci. 73(7): 1015-1030. doi:10.1139/cjfas-2015-0345.

R Development Core team, R.D.C. 2016. R: A Language and Environment for Statistical Computing. R Found. Stat. Comput. doi:10.1007/978-3-540-74686-7.

Reijnders, P., Brasseur, S.M.J.M., Tougaard, S., Seibert, U., Borchardt, T., and Stede, M. 2010. Population development and status of harbour seals (Phoca vitulina) in the Wadden Sea. NAMMCO Sci. Publ. 8: 95-106. doi:10.7557/3.2677.

Reis-Henriques, M.A., Silva, L., and Coimbra, J. 1996. Gill Na+-K+ ATPase, carbonic anhydrase activities and plasma osmotic and ionic variations during smoltification of Atlantic salmon in the north of Portugal. Aquacult. Int. 4(2): 117-128. doi:10.1007/BF00140593.

Rideout, R.M., Rose, G.A., and Burton, M.P.M. 2005. Skipped spawning in female iteroparous fishes. Fish Fish. 6(1): 50-72. doi:10.1111/j.1467-2679.2005.00174.x.

Rodgers, J.D., Ewing, R.D., and Hall, J.D. 1987. Physiological Changes during Seaward Migration of Wild Juvenile Coho Salmon ( Oncorhynchus kisutch ). Can. J. Fish. Aquat. Sci. 44(2): 452-457. doi:10.1139/f87-053.

Rolandsen, C.M., Solberg, E.J., Sæther, B.E., Moorter, B. Van, Herfindal, I., and Bjørneraas, K. 2017. On fitness and partial migration in a large herbivore - migratory moose have higher reproductive performance than residents. Oikos, 126(4): 547-555. doi:10.1111/oik.02996.

Salinger, D.H., and Anderson, J.J. 2006. Effects of Water Temperature and Flow on Adult Salmon Migration 
Swim Speed and Delay. Trans. Am. Fish. Soc. 135(1): 188-199. doi:10.1577/T04-181.1.

Samarin, A.M., Policar, T., and Lahnsteiner, F. 2015. Fish Oocyte Ageing and its Effect on Egg Quality. Rev. Fish. Sci. Aquacult. 23(3): 302-314. doi:10.1080/23308249.2015.1053560.

Saoud, I.P., Kreydiyyeh, S., Chalfoun, A., and Fakih, M. 2007. Influence of salinity on survival, growth, plasma osmolality and gill $\mathrm{Na}+-\mathrm{K}+-\mathrm{ATPase}$ activity in the rabbitfish Siganus rivulatus. J. Exp. Mar. Biol. Ecol. 348(1-2): 183-190. doi:10.1016/j.jembe.2007.05.005.

Schwinn, M., Baktoft, H., Aarestrup, K., and Koed, A. 2017. A comparison of the survival and migration of wild and F1-hatchery-reared brown trout (Salmo trutta) smolts traversing an artificial lake. Fish. Res. 196(February): 47-55. doi:10.1016/j.fishres.2017.08.011.

Schwinn, M., Baktoft, H., Aarestrup, K., Lucas, M.C., and Koed, A. 2018. Telemetry observations of predation and migration behaviour of brown trout (Salmo trutta) smolts negotiating an artificial lake. River Res. Appl. 34(8): 898-906. doi:10.1002/rra.3327.

Simpson, R.R., and Mapleston, A.J. 2002. Movements and habitat use by the endangered Australian freshwater Mary River cod, Maccullochella peelii mariensis. Environ. Biol. Fishes 65(4): 401-410. doi:10.1023/A:1021129021451.

Skaala, Ø., Kålås, S., and Borgstrøm, R. 2014. Evidence of salmon lice-induced mortality of anadromous brown trout ( Salmo trutta ) in the. Mar. Biol. Res. 10(3): 279-288. doi:10.1080/17451000.2013.810756.

Skall, H.F., Kjær, T.E., and Olesen, N.J. 2004. Investigation of wild caught whitefish, Coregonus lavaretus (L.), for infection with viral haemorrhagic septicaemia virus (VHSV) and experimental challenge of whitefish with VHSV. J. Fish Dis. 27(7): 401-408. doi:10.1111/j.1365-2761.2004.00554.x.

Sobocinski, K.L., Greene, C.M., and Schmidt, M.W. 2018. Using a qualitative model to explore the impacts of ecosystem and anthropogenic drivers upon declining marine survival in Pacific salmon. Environ. Conserv. 45(3): 278-290. doi:10.1017/S0376892918000073.

Stich, D.S., Kinnison, M.T., Kocik, J.F., and Zydlewski, J.D. 2015. Initiation of migration and movement rates of Atlantic salmon smolts in fresh water. Can. J. Fish. Aquat. Sci. 72(9): 1339-1351. doi:10.1139/cjfas-2014-0570.

Stoltze, M., and Pihl, S. 1998. RØDLISTE 1997 over planter og dyr i Danmark. Miljø- og Energiministeriet, Danmarks Miljøundersøgelser og Skov- og Naturstyrelsen.

Svendsen, J.C., Aarestrup, K., Malte, H., Thygesen, U.H., Baktoft, H., Koed, A., et al. 2011. Linking individual behaviour and migration success in Salmo salar smolts approaching a water withdrawal site: implications for management. Aquat. Living Resour. 24: 201-209.

Svendsen, J.C., Alstrup, A.K.O., and Jensen, L.F. 2018. World Heritage Site fish faces extinction. Nature 556(7700): 174. doi:10.1038/d41586-018-04169-2.

Svendsen, J.C., Koed, A., and Aarestrup, K. 2004. Factors influencing the spawning migration of female anadromous brown trout. J. Fish Biol. 64: 528-540. doi:10.1046/j.1095-8649.2003.00319.x.

Taylor, M.K., and Cooke, S.J. 2014. Repeatability of movement behaviour in a wild salmonid revealed by telemetry. J. Fish Biol. 84(4): 1240-1246. doi:10.1111/jfb.12334.

Thomas, A.C., Nelson, B.W., Lance, M.M., Deagle, B.E., and Trites, A.W. 2017. Harbour seals target juvenile salmon of conservation concern. Can. J. Fish. Aquat. Sci. 74(6): 907-921. doi:10.1139/cjfas2015-0558.

Thorstad, E.B., Økland, F., Aarestrup, K., and Heggberget, T.G. 2008. Factors affecting the within-river spawning migration of Atlantic salmon, with emphasis on human impacts. Rev. Fish Biol. Fish. 18: 345-371. doi:10.1007/s11160-007-9076-4.

Thorstad, E.B., Todd, C.D., Uglem, I., Arne, P., Gargan, P.G., Wiik, K., et al. 2016. Marine life of the sea trout. Mar. Biol. 163(3): 1-19. doi:10.1007/s00227-016-2820-3.

Vardanis, Y., Nilsson, J.-Å., Klaassen, R.H.G., Strandberg, R., and Alerstam, T. 2016. Consistency in longdistance bird migration: contrasting patterns in time and space for two raptors. Anim. Behav. 113(Supplement C): 177-187. doi:https://doi.org/10.1016/j.anbehav.2015.12.014.

Villegas-Ríos, D., Réale, D., Freitas, C., Moland, E., and Olsen, E.M. 2017. Individual level consistency and correlations of fish spatial behaviour assessed from aquatic animal telemetry. Anim. Behav.

124(Supplement C): 83-94. doi:https://doi.org/10.1016/j.anbehav.2016.12.002.

Wiese, F.R.K.W., Parrish, J.K, Thompson, C.W, and Maranto, C. 2008. ECOSYSTEM-BASED 
MANAGEMENT OF PREDATOR - PREY RELATIONSHIPS : PISCIVOROUS BIRDS AND SALMONIDS. Ecol. Appl. 18(3): 681-700.

Wilson, A.D.M., Hayden, T.A., Vandergoot, C.S., Kraus, R.T., Dettmers, J.M., Cooke, S.J., and Krueger, C.C. 2017. Do intracoelomic telemetry transmitters alter the post-release behaviour of migratory fish? Ecol. Freshw. Fish, 26(2): 292-300. doi:10.1111/eff.12275.

Wright, B.E., Riemer, S.D., Brown, R.F., Ougzin, A.M., and Bucklin, K.A. 2007. Assessment of harbor seal predation on adult salmonids in a Pacific Northwest estuary. Ecol. Appl. 17(2): 338-351. doi:10.1890/05-1941.

Young, G., McCormick, S.D., Björnsson, B.T., and Bern, H.A. 1995. Circulating growth hormone, cortisol and thyroxine levels after $24 \mathrm{~h}$ seawater challenge of yearling coho salmon at different developmental stages. Aquaculture, 136(3-4): 371-384. doi:10.1016/0044-8486(95)01069-6.

Zuur, A.F., Ieno, E.N., Walker, N., Saveliev, A. and Smith, G.M. 2009. Mixed effects models and extensions in ecology with R. In Mixed Effects Models and Extensions in Ecology with R. Springer New York, New York, NY. 323-339. doi:10.1007/978-0-387-87458-6.

Figure legends

Figure 1. Map of the study area. The map includes the River Vidaa in South Denmark and the 16 stationary acoustic receivers positioned in the river, numbered 16-1. The river drains into the Wadden Sea at receiver 16. Sections A and B cover natural river sections, whereas sections D and E cover artificial lakes. Section C covers a natural lentic area. Modified from Jensen et al. $2018 b$ (Jensen, L.F., Rognon, P., Aarestrup, K., Bøttcher, J.W., Pertoldi, C., Thomsen, S.N., Hertz, M., Winde, J., and Svendsen, J.C. $2018 b$. Evidence of cormorant-induced mortality, disparate migration strategies and repeatable circadian rhythm in the endangered North Sea houting (Coregonus oxyrinchus): a telemetry study mapping the postspawning migration. Ecol. Freshw. Fish, 27(3): 672-685. doi:10.1111/eff.12383. Reproduced by permission of John Wiley and Sons.)

Figure 2 . The probability of river entry $(0=$ no entry, $1=$ entry $)$ as a function of [a] temperature $\left({ }^{\circ} \mathrm{C}\right)$ and $[\mathrm{b}]$ river discharge $\left(1 \mathrm{~s}^{-1}\right)$ in North Sea houting (Coregonus oxyrinchus). Each relationship was fitted using 
logistic regression. The probability of river entry varied significantly with temperature and discharge. Low water temperatures and high river discharges elevated the probability of river entry.

Figure 3. River discharge $\left(1 \mathrm{~s}^{-1}\right)(\bullet)$ and water temperature $\left({ }^{\circ} \mathrm{C}\right)(\circ)$ were measured throughout the study period.

Figure 4. North Sea houting (Coregonus oxyrinchus) migration speeds $\left(\mathrm{km} \mathrm{h}^{-1}\right)$ through river sections (sections A and B), the lentic Magisterkog (C) and the artificial Lake Hestholm Kog (D) and Lake Nørresø (E). Upper and lower 95\% CI are shown with bars. Significant differences between sections are indicated by different letters $(\mathrm{P}<0.05)$. See map in Fig. 1 for details. The slowest migration speeds were observed when the fish travelled through artificial lakes.

Figure 5. Values of gill $\mathrm{Na}^{+} / \mathrm{K}^{+}$ATPase-activity ( $\mu$ moles/ mg protein/ hour) and blood osmolality (mOsmol/ $\mathrm{kg}$ ) differ between North Sea houting and resident (R) and anadromous (A) European whitefish. [a] $\mathrm{Na}^{+} / \mathrm{K}^{+}$ ATPase activity is significantly higher in North Sea houting and anadromous whitefish compared to resident whitefish. [b] Osmolality is significantly higher in North Sea houting compared to both anadromous and resident whitefish. 


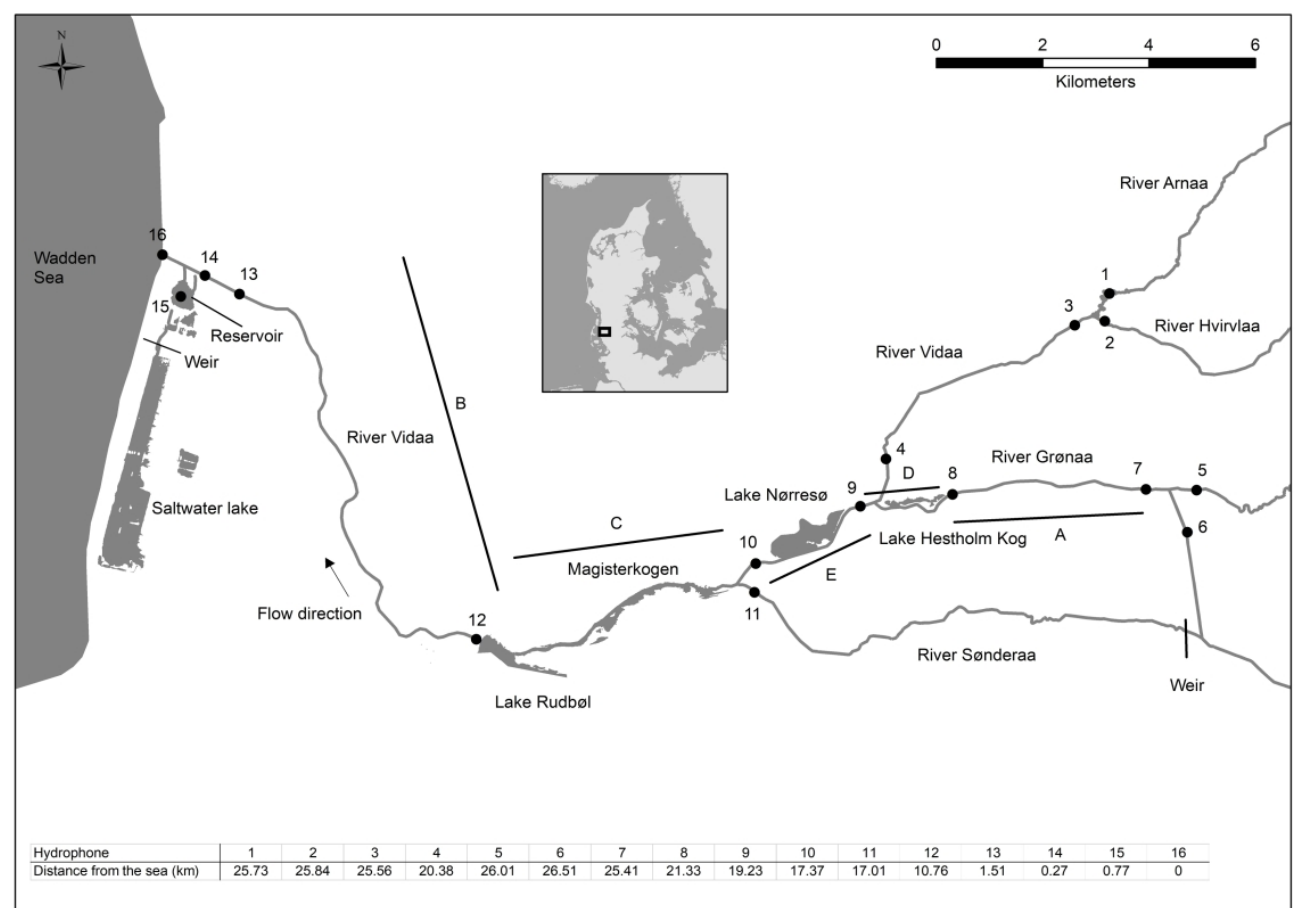

Figure 1. Map of the study area. The map includes the River Vidaa in South Denmark and the 16 stationary acoustic receivers positioned in the river, numbered 16-1. The river drains into the Wadden Sea at receiver 16. Sections A and B cover natural river sections, whereas sections D and E cover artificial lakes. Section C covers a natural lentic area. Modified from Jensen et al. 2018b. (Jensen, L.F., Rognon, P., Aarestrup, K., Bøttcher, J.W., Pertoldi, C., Thomsen, S.N., Hertz, M., Winde, J., and Svendsen, J.C. 2018. Evidence of cormorant-induced mortality, disparate migration strategies and repeatable circadian rhythm in the endangered North Sea houting (Coregonus oxyrinchus): a telemetry study mapping the postspawning migration. Ecol. Freshw. Fish, 27(3): 672-685. doi:10.1111/eff.12383. Reproduced by permission of John Wiley and Sons.)

$296 \times 209 \mathrm{~mm}(300 \times 300$ DPI) 

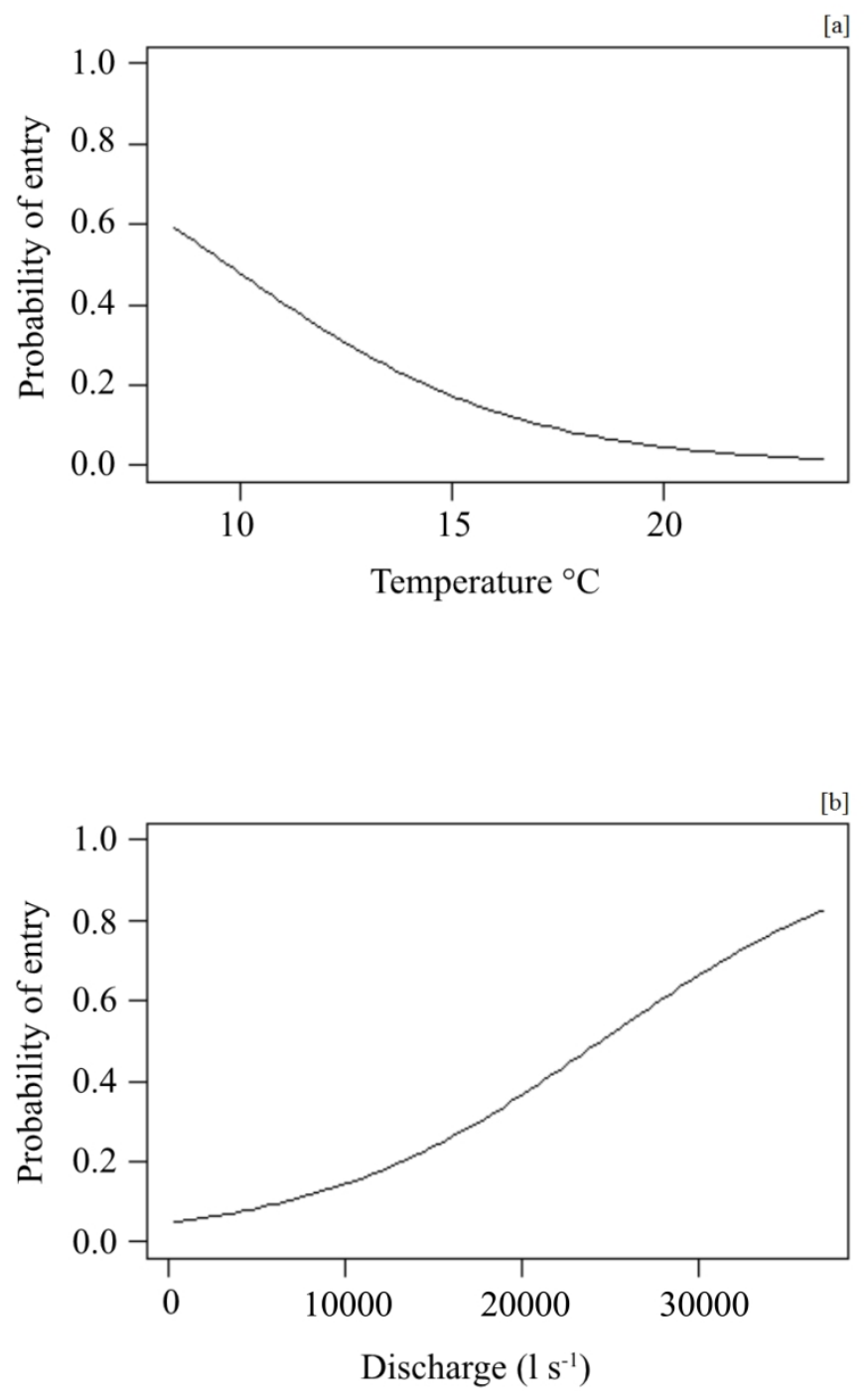

Figure 2 . The probability of river entry $(0=$ no entry, $1=$ entry $)$ as a function of $[\mathrm{a}]$ temperature $\left({ }^{\circ} \mathrm{C}\right)$ and [b] river discharge (I s-1) in North Sea houting (Coregonus oxyrinchus). Each relationship was fitted using logistic regression. Temperature and discharge varied significantly with the probability of river entry. Low water temperatures and high river discharges elevated the probability of river entry. 


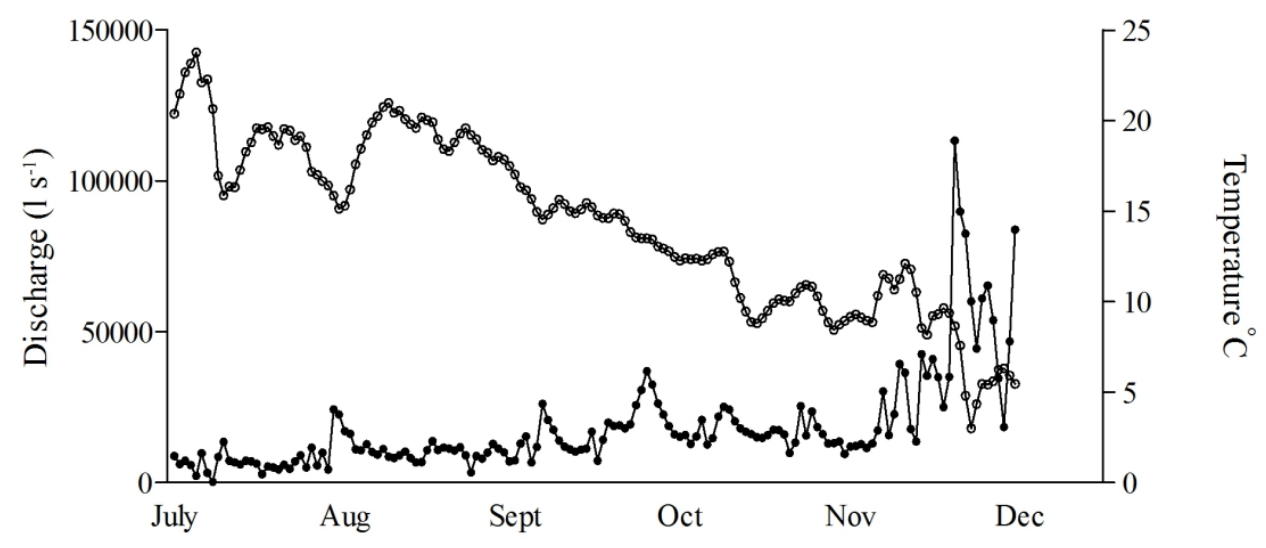

Figure 3. River discharge $(\mathrm{I} \mathrm{s}-1)(\bullet)$ and water temperature $\left({ }^{\circ} \mathrm{C}\right)(\circ)$ were measured throughout the study period.

$163 \times 73 \mathrm{~mm}(300 \times 300 \mathrm{DPI})$ 


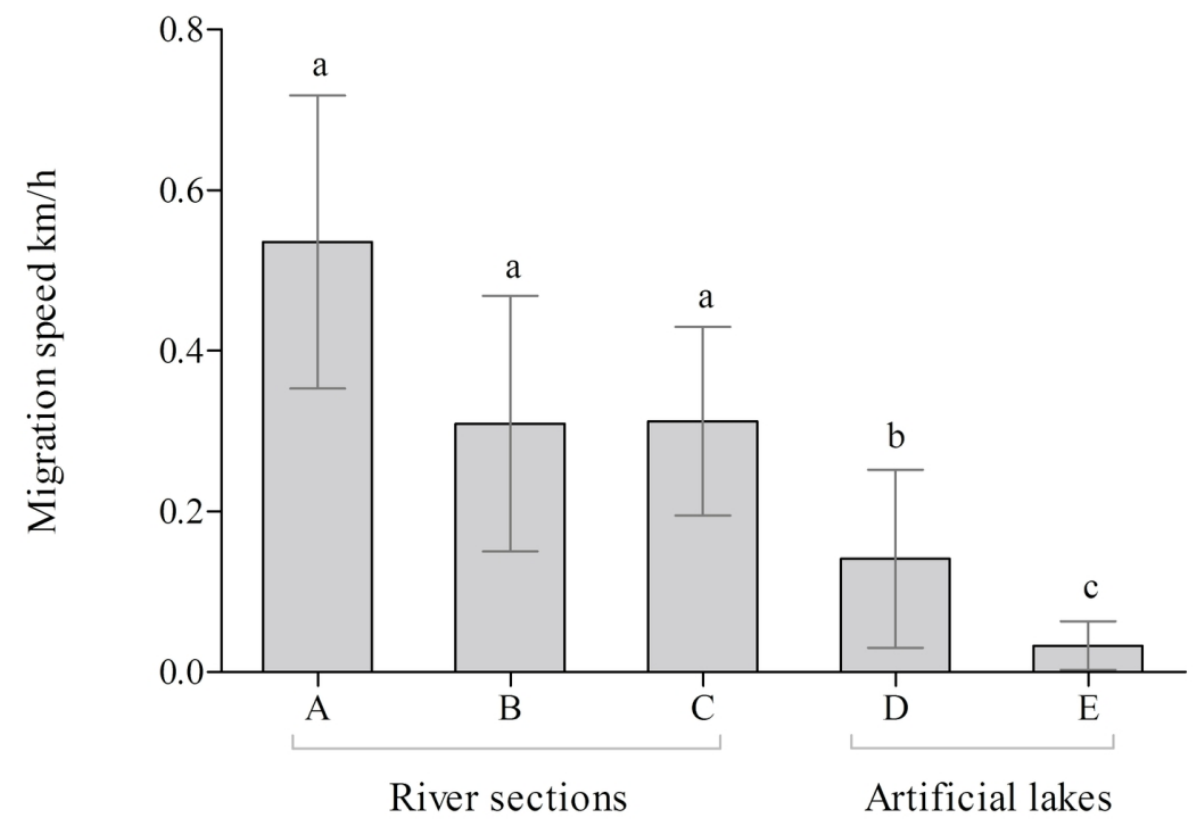

Figure 4. North Sea houting (Coregonus oxyrinchus) migration speeds ( $\mathrm{km} \mathrm{h}-1$ ) through river sections (sections A and B), the lentic Magisterkog (C) and the artificial Lake Hestholm Kog (D) and Lake Nørresø (E). Upper and lower 95\% CI are shown with bars. Significant differences between sections are indicated by different letters $(P<0.05)$. See map in Fig. 1 for details. The slowest migration speeds were observed when the fish travelled through artificial lakes.

$135 \times 97 \mathrm{~mm}(300 \times 300 \mathrm{DPI})$ 


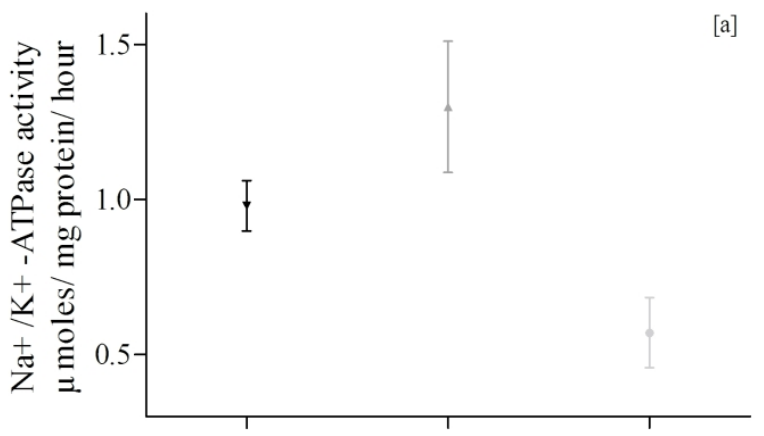

[a]
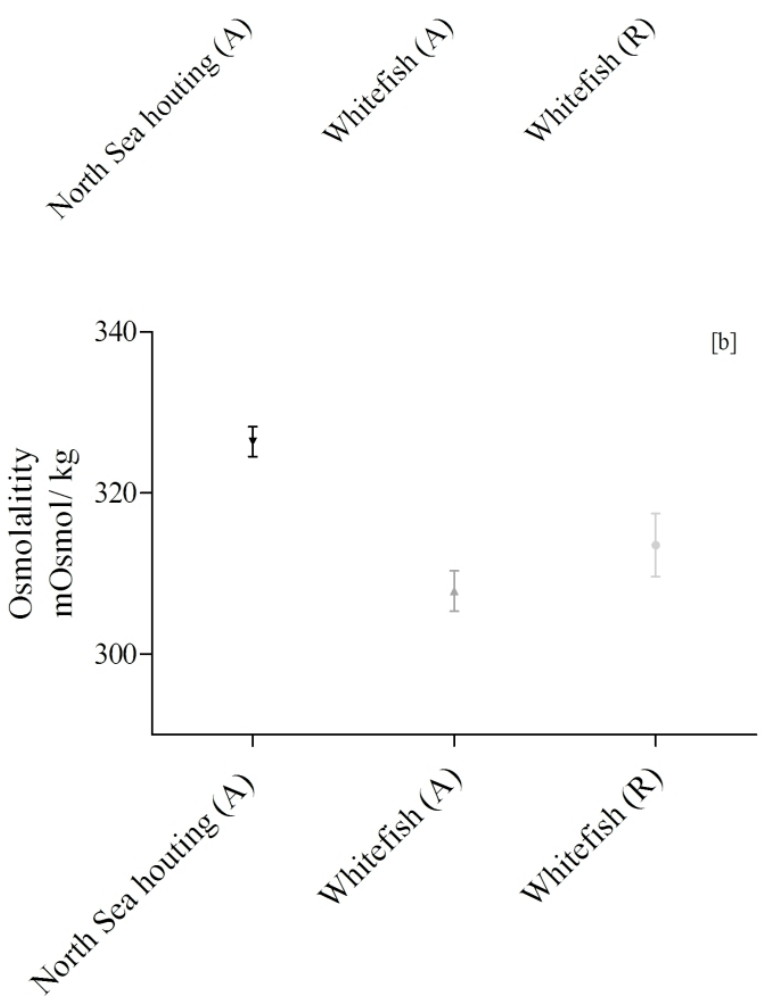

Figure 5. Values of gill $\mathrm{Na}+\mathrm{K}+$ ATPase-activity ( $\mu$ moles/ mg protein/ hour) and blood osmolality (mOsmol/ $\mathrm{kg}$ ) differ between North Sea houting and resident and anadromous European whitefish. [a] $\mathrm{Na}+/ \mathrm{K}+$ ATPase activity is significantly higher in North Sea houting and anadromous whitefish compared to resident whitefish. [b] Osmolality is significantly higher in North Sea houting compared to anadromous and resident whitefish.

$145 \times 268 \mathrm{~mm}(300 \times 300 \mathrm{DPI})$ 